\title{
Dividend and leverage in Indonesian intergenerational family firms
}

\author{
Aldo Santos, Elvira Rindra, Athalia Ariati Hidayat*, Yang Elvi Adelina \\ Universitas Prasetiya Mulya, Jakarta, Indonesia \\ *Corresponding author: athalia.ariati@pmbs.ac.id
}

\begin{abstract}
This paper analyzes the relationships between family ownership and family generation toward dividend payout and leverage in publicly listed Indonesian firms from 2012 until 2016. The research contributes to explaining relationship between family generations toward dividend payouts and leverage in Indonesian family firms. Samples gathered by the purposive sampling method and random effect regression results show significant negative and positive relationships between family ownership and dividend and leverage, respectively. Family as the majority shareholder pays a lower dividend while employing additional supervision from creditors received as a result of using leverage as a control mechanism to mitigate agency problems. Research into family generation shows a significant positive relationship between descendantcontrolled firms and dividend payout, which is in line with the income needs perspective, but an insignificant relationship for leverage. Limitations regarding information force this study to exclude the percentage of ownership and use only judgment to classify family-owned firms and generational stage. With proven expropriation activities toward minority shareholders, family firms can increase transparency and improve corporate governance practice.
\end{abstract}

Keywords: family firms, family generation, dividend, leverage JEL Classification Code: G12 DOI: $10.20885 /$ jsb.vol24.iss1.art4

\section{Introduction}

The Indonesian Family Business Survey conducted by Pricewaterhouse Coopers in 2014 shows that more than $95 \%$ of businesses in Indonesia are family-owned, with growth rates over the past 12 months reaching $83 \%$ (65\% globally). This fact demonstrates the significance of the Indonesian family business to Indonesia's overall economy. A family business is defined as a company that is owned and controlled by the founder or founding family (Claessens, Djankov \& Lang, 2000). Family acts as the majority shareholder and receives control of the company; therefore, family becomes the controlling shareholder. Asian Development Bank (2000) research indicates that 85\% of companies with concentrated ownership place the founding families as top management. Since families serve as both owner or shareholder (principal) and manager (agent), there is an alignment of interests. This view is slightly different from agency theory (Jensen \& Meckling, 1976), which argues the possibility of a conflict of interest between shareholders (principal) and managers (agent). One reason this principal-agent conflict arises is the availability of cash or free cash flow, which can be minimized through dividend payments and leverage (Faccio, Lang, \& Young 2001a; Jensen, 1986; La Porta, Lopez-de-Silanes, Shleifer \& Vishny, 2000; Setia-Atmaja, 2010).

A negative relationship between family ownership and dividend payments is shown mainly from research in Indonesia (Duygun, Guney \& Moin, 2018; Moin, Guney \& El Kalak, 2019; Setia-Atmaja, 2017; Setiawan, Bandi, Kee Phua \& Trinugroho, 2016) and Hong Kong (Chen, Cheung, Stouraitis \& Wong, 2005). Similarly, Faccio et al. (2001a) show a lower dividends payment in Asia where there are multiple large shareholders. Duygun, Guney, and Moin (2018) state that the negative relationship may be due to either the family firm's vulnerability to the expropriation of minority shareholders or its preservation of earnings to support internal financing. Meanwhile, a positive relationship is found in Australia (Setia-Atmaja, Tanewski \& 
Skully, 2007;), Switzerland (Isakov \& Weisskopf, 2015), and also in the manufacturing firm sample in Indonesia (Setianto \& Sari, 2017).

Besides dividends, debt can also be used to facilitate expropriation of the minority shareholders by allowing controlling shareholders to manage more resources (Faccio, Lang, \& Young, 2001b). Lean, Ting, and Kweh (2015) in a research in Malaysian public companies prove that lower debt level is found in firms with greater monitoring as in family firms. On the other hand, Lo, Ting, Kweh, and Yang (2016) found a nonlinear reversed U-shape relationship between concentration of ownership rights and debt level.

Previous studies have also examined family firms and their relationship to both dividends and leverage. However, the results are inconsistent among countries. In Indonesia, Mulyani, Singh \& Mishra (2016) explain that family firms pay lower dividends but have higher leverage compared to non-family firms, which indicate that family-controlled firms in Indonesia use leverage instead of dividends to manage agency conflict. Yet, in a study in Australia, SetiaAtmaja (2010) states families tend to pay higher dividends and employ higher debt level, that is strengthened by the significant role of board independence in family firms.

Some family firms are led by the founders, while others are passed on to descendants. The family generation is able to affect emotional attachment (Sciascia, Mazzola \& Kellermanns, 2014), as well as a firm's performance and risk tolerance (Pérez-González, 2006; Villalonga \& Amit, 2006). Toward its dividend policies, Isakov \& Weisskopf (2015) show that descendantstage firms pay slightly more in dividends than other family firms, while Setianto and Sari (2017) state that family generation does not have impact to dividend policy. Toward leverage, Bobillo, Rodriguez-Sanz, and Tejerina-Gaite (2013) demonstrate that descendants are less risk-averse than the founders when it comes to obtaining debt financing.

This research contributes to examine the relationship between family firms toward dividend and leverage, and also family generation toward dividend and leverage. The vast numbers of family firms in Indonesia and the fact that Indonesia has low investor protection (La Porta, Lopez-de-Silanes \& Shleifer, 1999) make this study more interesting. With the addition of new periods, variables, and types of industries, this research provides the latest update and analysis of Indonesian family firms and the later generation stage of family firms.

\section{Literature Review}

According to Eisenhardt (1989), agency theory focuses on solving two main agency problems: (1) those that arise when there are differences in objectives between principal-agents and the emergence of circumstances when the principal has difficulty in ascertaining what actions are actually carried out by the agent and (2) when there is a difference in risk tolerance between principal and agents. Villalonga \& Amit (2006) introduce two types of agency problems. Type I agency problems involve the separation of controls between company owners and management, as Jensen \& Meckling (1976) explain. Type II agency problems address the problems in the majority shareholder and minority shareholder relationship. Agency problems between the majority and minority can occur in the form of expropriation, which is the majority shareholders' use of controls to take actions that harm minority shareholders. Johnson, La Porta, Lopez-de-Silanes, and Shleifer (2000) describe the concept of expropriation as "tunneling," which is an act of transferring assets or profits from a company for the benefit of those who have control over the company. This expropriation activity is even more significant if certain shareholdings and control over a company are increased and the company is majority owned by certain parties; this applies to family companies with concentrated ownership, as found in Indonesia (Claessens et al., 2000).

Two perspectives on agency relationships exist in family firms. First, the presence of family as both shareholder and manager can improve supervision and monitoring, thereby increasing employee loyalty and producing a more effective dividend policy. This way, the family does not expropriate the firm's available cash or the family is considered to produce an "alignment effect" 
(Wang, 2006), so that the agency problems found in family companies are considered smaller than the agency problems that arise in non-family companies (Anderson \& Reeb, 2003; Setia-Atmaja et al., 2007). However, on the contrary, family as majority shareholders can affect the firm negatively through the possibility of expropriation (transfer of the firm's assets to benefit the majority shareholders at the expense of minority shareholders). This perspective is called the "entrenchment effect" (Wang, 2006). This second perspective sees family as the main shareholders who have control over the company; family members may have access and the ability to abuse company assets for personal gain at the expense of minority shareholders (Easterbrook, 1984; Shleifer \& Vishny, 1997). Legal protection for weak investors in Indonesia (Claessens et al., 2000) can also cause expropriation activities to be increasingly rampant among family members.

Several definitions of family firms exist. Miller et al. (2007) present various related definitions of family ownership that have been used in several studies; one such definition is an organization that is controlled and managed by several family members from several generations, by a founding family, or by an individual founder.

Some researchers classify family firms based on the percentage of family ownership, such as Barth, et al. (2005), who designate at least 33\% of share ownership, and Ang, Cole, and Lin (2000), who refer to a minimum of 50\% share ownership. Holderness and Sheehan (1988) use a minimum ownership of $50.1 \%$. Family members in top management can also serve as a determinant of whether a company is classified as a family firm. Denis and Denis (1994, in Miller et al., 2007) define a family firm as having two or more family members who work as employees or sit in top management or the founder as an internal employee of the company. Meanwhile defines family firms based on whether the chief executive officer (CEO) of the company is the founder.

Anderson and Reeb (2003a) argue that a family firm is defined by whether a founding family has share ownership and/or the presence of family members who hold top positions in the company's management. Indonesia imposes a regulation related to family ownership originating from the decision of the directors of the Jakarta Stock Exchange (JSX) No. Kep-305/BEJ/07-2004. This regulation explains that a shareholder can be referred to as a controlling shareholder if he or she owns $25 \%$ or more of the company's shares. This research will use the definition of family firm from Anderson and Reeb (2003a) because their definition portrays the condition of family firms in Indonesia, that is, having family members in the top management of the company while also having some percentage of share ownership.

\section{Family Ownership and Dividend Payout}

Two perspectives can illustrate the agency relationship in the company: agency theory type I and agency theory type II (Villalonga \& Amit, 2006). The first perspective of agency theory discusses the problem arising due to separation of control between shareholder and management. This theory suggests that the role of the family in a company has a positive impact because the family is considered capable of delivering better supervision of the company, so the agency problem in family firms is considered smaller than that in non-family firms (Anderson and Reeb, 2003a; Setia-Atmaja et al., 2007). The first type of agency theory also has an alignment effect because the family presence can reduce agency costs and provide more effective supervision of management (Wang, 2006).

The presence of families who perform active supervision within the company can improve dividend payment. This is because dividends are considered a mechanism or control device that can reduce the availability of cash that might be expropriated by a manager. Higher dividend distribution can also improve the company's reputation through better signals regarding future earnings predictions. Signaling theory explains that managers, as parties who know more information about the company, can use dividends to increase the credibility of the signal related to the company's information (Rankin et al., 2012). 
On the other hand, the second perspective of agency theory discusses the relationship between the majority and minority shareholders. This second type of agency theory assumes that the family members, as major shareholders who have control over the company, have access to and the ability to abuse company assets for personal interests at the expense of minority shareholders (Easterbrook, 1984; Shleifer \& Vishny, 1997). In other words, family members can cause an entrenchment effect. Nonetheless, Indonesia's low protection for investors (La Porta et al., 1999) increases families' potential as controlling shareholders who act in accordance with their interests, which may not be appropriate or consistent with the interests of minority shareholders who have a lower degree of control over the company. This activity can also be referred to as "tunneling" (Johnson et al., 2000).

Vieira (2011) and Moin et al. (2019) support the understanding of expropriation and show that the level of dividend payments to family companies is lower than that of non-family companies. With a lower level of dividends in family firms, minority shareholders are prone to expropriation by the controlling family shareholders (Duygun et al., 2018). The same research results were also proven in Indonesia (Mulyani et al., 2009; Setia-Atmaja, 2017; Setiawan et al., 2016), East Asia (Attig, et al., 2016), and China (Wei, et al., 2011). Therefore, the following hypothesis is formulated:

H1: Family ownership is negatively related to dividend payout in Indonesia's public companies.

\section{Family Ownership and Leverage}

Jensen (1986) argues that leverage or debt can also be used as a substitute for dividends to minimize agency problems in the company. This idea is related to the use of debt to increase the company's obligation to use free cash flow as a source of payment of principal or interest expense in the future. Leverage can also be associated with corporate funding sources, which are explained by pecking order theory: Companies choose funding sources for their investment activities based on the order of risk (Myers \& Majluf, 1984).

Family firms may be more likely to increase leverage or the level of debt compared to equity because of the possibility that the proportion of share ownership is diluted, thus reducing the family's control of the company. On the other hand, family firms will also consider the credit risk the company faces. Shleifer and Vishny (1986) mention that more family companies choose to look for sources of capital with lower default risk, which results in high dependency on equity and low leverage. Faccio et al. (2001b) also mention that families prefer low leverage to reduce payment obligations.

Nevertheless, according to the concept of expropriation (Claessens et al., 2000) and weak protection of minority investors, family companies in Indonesia tend to use debt, especially bank loans, as funding rather than cash. Based on Mulyani et al. (2016), one can conclude that family companies in Indonesia most likely use debt to mitigate agency problems. This is because even though debt increases credit risk, there is additional supervision from creditors if the company uses debt for funding (Isakov \& Weisskopf, 2015). Family companies also have lower debt costs than non-family companies, consistent with the use of personal wealth as collateral (Keasey et al., 2015) and undiversified portfolios (Anderson at al., 2003). Therefore, one can conclude that family companies have a high level of debt compared to non-family companies. This statement has been proven through research from Setia-Atmaja et al. (2010) in Australia, so the following hypothesis is proposed:

H2: Family ownership is positively related to leverage in Indonesia's public companies.

\section{Family Generation and Dividend Payout}

Setianto and Sari (2017) explain the effect of family generation on dividend payout using lifecycle theory. Family firms that are still run by the founding generation tend to focus their 
activities to introduce products to consumers (introduction stage). Next, the descendants focus on developing the company through expansion and investments that require large funds (growth stage). As a result, the perception arises that family companies led by the founder as well as the descendants prefer to reinvest funds for expansion rather than distributing the funds in the form of dividends. Furthermore, Muttakin at al. (2014) show that the founder-led family firm tends to reinvest the company's returns for the sustainability of the next generation. This can result in reduced dividends distributed to shareholders.

On the other hand, Anderson et al. (2003) report that on average, based on Forbes "Wealthiest Americans" data, families had more than $69 \%$ of their wealth invested in their family company. The more generations involved in the company, the more family members invest their wealth and depend on the business as their source of income. This is consistent with the views on family income needs presented by Isakov and Weisskopf (2015) through their research on family companies in Switzerland. Their study reports that family ownership has two characteristics. First, as a company owner, the family places most of their wealth in the company. In addition, families also want to remain in control of the company in the long term, so selling their ownership of the company is not an option for earning income for the family. Therefore, families expect a higher level of dividend payments from family companies, as the place where they put most of their wealth.

The influence of family companies on the level of dividend payment is mostly determined by the number of family members in the company. The dividend rate increases as more family members demand a return from the firm. In addition, an increasing number of family members within a company generally means a higher likelihood that family members have no interest in development of the company. Therefore, dividends can be used as an incentive to increase the active role of family members in development of the company. This is also supported by Isakov \& Weisskopf (2015), who prove that family companies led by descendants have higher dividend rates than family companies led by the founder. This higher dividend rate acts as compensation because not all family members of the descendants earn income through their active positions in company management. Therefore, the third hypothesis of this study is as follows:

H3: Family companies led by descendants are positively related to the distribution of dividends in Indonesia.

\section{Family Generation and Leverage}

Family firms led by the next generation, who are younger than the founding generation, are more open-minded, modern, and likely to take risk. For example, Muñoz-Bullon, Sanchez-Bueno, \& Suárez-González (2018) show that the next generation tends to set diversification strategies in comparison to the generation of founders. In addition, the next generation also tends to intensify investing activities. In accordance with pecking order theory, which states that the company is more likely to use debt than equity as a source of funds, the large funding needed for these investments also increases the level of debt.

In contrast, as business continues, the descendants tend to focus more on the rate of return for the period when they hold a position in the firm as opposed to the sustainability of the company to be passed on to the next generation. This perspective results from the reduced active role and sense of ownership of the descendants. Sciascia et al. (2014) support this view by reporting that future generations have lower emotional linkages, along with different needs, commitments, and priorities. The descendants prefer to increase the company's return, also known as financial wealth. Gómez-Mejía, Haynes, Núñez-Nickel, Jacobson, and Moyano-Fuentes (2007) describe socioemotional wealth as a need for non-financial aspects of the company, such as ownership identity, ability to influence company policy, and the continuity of family descendants in the ownership and culture of the company. The founding generation, with a desire for higher socioemotional wealth, shows that families are willing to face the risk of poor company 
performance to maintain family control rights and conservative tendencies. Gómez-Mejía et al. (2007) find that family companies choose to continue to maintain their control over the company, even though their decision might increase performance hazards. This includes the negative consequences that the company receives due to certain decisions, which can occur in the form of a higher probability of bankruptcy and performance that does not reach target. Therefore, this view of socioemotional wealth can explain the different management orientations between family companies run by different generations.

Due to the descendant who prioritizes the improvement of financial wealth, an increase in debt accompanied by an increase in interest payments reduces profitability and, ultimately, the descendant will reduce the level of debt held. In addition, debt can be used as alternative funding for families to avoid dilution of share ownership through equity funding. Keasey, Martinez, \& Pindado (2015) argue that the founding generation with a higher sense of ownership and the desire to continue to the next generation will avoid using equity as funding so that the ownership will not be diluted and will use loans to develop the company. Therefore, the fourth hypothesis of this study is as follows:

H4: Family companies led by descendants are negatively related to the level of leverage in Indonesia.

\section{Methods}

\section{Population and Sample}

The initial sample comprises annual panel data from non-financial companies listed on the Indonesia Stock Exchange (IDX) from 2012 through 2016. The sampling technique was purposive sampling, included as a nonprobability sampling method. For research that examines the effect on the level of dividend payment, companies included as samples in the study must have had a positive earnings balance. This excludes companies that have not distributed dividends due to the company's inability to pay dividends. In addition, for studies that examine the influence of family generations, the sample used is restricted to companies classified as family firms. Financial data are obtained through Capital IQ and are complemented with data from the company's financial statements, while the information in the dummy classification is obtained from annual reports, financial reports, and other internet sources. The criteria for the samples are explained in Tables 1 and 2.

Table 1. Gathering of Research Sample (for Hypotheses 1 and 2)

\begin{tabular}{lcc}
\hline \multicolumn{1}{c}{ Sample Criteria } & Total Firms & Total Observations \\
\hline Firms listed on IDX from 2012 to 2016 & 536 & 2,462 \\
Financial firms & $(93)$ & $(410)$ \\
Incomplete financial data & & $(20)$ \\
Unpublished financial report & & $(11)$ \\
\hline Total observations (Sample for Hypothesis 2) & 443 & 2,021 \\
\hline Negative retained earning & & $(537)$ \\
\hline Total observations (Sample for Hypothesis 1) & 366 & 1,484 \\
\hline
\end{tabular}

Table 2. Gathering of Research Sample (for Hypotheses 3 and 4)

\begin{tabular}{lcccc}
\hline \multirow{2}{*}{ Sample Criteria } & \multicolumn{2}{c}{ For Hypothesis 3 } & \multicolumn{2}{c}{ For Hypothesis 4 } \\
\cline { 2 - 5 } & Total Firms & $\begin{array}{c}\text { Total } \\
\text { Observations }\end{array}$ & Total Firms & Total Observations \\
\hline Total observations & 366 & 1,484 & 443 & 2,021 \\
Non-family firm & $(75)$ & $(305)$ & $(87)$ & $(392)$ \\
\hline Family firm & 291 & 1,179 & 356 & 1,629 \\
\hline
\end{tabular}




\section{Definition of Variables}

Table 3 provides the definition of each research variable. The dependent variable in this study consists of the level of dividend payment and leverage. In accordance with previous research, such as Mulyani et al. (2016), La Porta et al. (2000), Faccio et al. (2001), and Setia-Atmaja et al. (2007), the level of dividend payment is measured using the dividend payout ratio, that is, dividing the amount of cash dividends on ordinary shares by the current year's net income at the end of the reporting period. Leverage is measured by comparing the total book value of liabilities with the total book value of assets at the end of the reporting period (Mulyani et al., 2016).

Table 3. Variable Definitions

\begin{tabular}{|c|c|c|}
\hline Variable Name & Definition & Reference \\
\hline \multicolumn{3}{|l|}{ Independent Variables } \\
\hline Family Ownership & $\begin{array}{l}\text { A dummy variable, equal to } 1 \text { if an individual or } \\
\text { founding family member has a percentage share of } \\
\text { ownership in the company and/or serves on the } \\
\text { board of commissioners or board of directors in the } \\
\text { company and } 0 \text { if both conditions are not met. }\end{array}$ & $\begin{array}{l}\text { Anderson \& Reeb } \\
(2003 a)\end{array}$ \\
\hline Family Generation & $\begin{array}{l}\text { A dummy variable separated into two other dummy } \\
\text { variables. The first is DFOUNDER, which is equal to } \\
1 \text { if the family company has a founding generation } \\
\text { that serves on the board of commissioners and/or } \\
\text { board of directors and } 0 \text { if these conditions are not } \\
\text { met. The second is DDESCENDANT, which is equal } \\
\text { to } 1 \text { if the family company has a descendant who } \\
\text { serves on the board of commissioners and/or board } \\
\text { of directors and } 0 \text { if these conditions are not met. }\end{array}$ & $\begin{array}{l}\text { Isakov \& Weisskopf } \\
(2015)\end{array}$ \\
\hline \multicolumn{3}{|l|}{ Dependent Variables } \\
\hline Payout & $\begin{array}{l}\text { Comparison between the number of cash dividends } \\
\text { on ordinary shares paid and net income at the end of } \\
\text { the reporting period. }\end{array}$ & $\begin{array}{l}\text { La Porta et al. (2000), } \\
\text { Faccio et al. (2001a), } \\
\text { Setia-Atmaja et al. (2007) }\end{array}$ \\
\hline Leverage & $\begin{array}{l}\text { Comparison between the total book value of } \\
\text { liabilities and the total book value of assets at the } \\
\text { end of the reporting period. }\end{array}$ & Mulyani et al. (2016) \\
\hline \multicolumn{3}{|l|}{ Control Variables } \\
\hline Cash Ratio & $\begin{array}{l}\text { Comparison between the amount of cash and total } \\
\text { assets of the company. }\end{array}$ & Farinha (2003) \\
\hline Growth Opportunities & Annual sales growth (last three years). & Setia-Atmaja (2017) \\
\hline Profitability & Return on assets (ROA). & $\begin{array}{l}\text { Lean et al. (2015), Pérez- } \\
\text { González (2006) }\end{array}$ \\
\hline Firm Size & $\begin{array}{l}\text { The natural logarithm of the total assets of the } \\
\text { company at the end of the reporting period. }\end{array}$ & $\begin{array}{l}\text { Setia-Atmaja et al. } \\
(2010)\end{array}$ \\
\hline Industry Sector & $\begin{array}{l}\text { Equal to } 1 \text { for the studied sector and } 0 \text { for the other } \\
\text { sectors. }\end{array}$ & Mulyani et al. (2016) \\
\hline Year & $\begin{array}{l}\text { Equal to } 1 \text { for the current year and } 0 \text { for the other } \\
\text { years. }\end{array}$ & $\begin{array}{l}\text { Anderson \& Reeb } \\
\text { (2003a), Setia-Atmaja } \\
\text { (2017), Mulyani et al. } \\
\text { (2016) }\end{array}$ \\
\hline
\end{tabular}


The first independent variable is family ownership. If a company is classified as a family firm, the dummy variable will equal 1 if an individual or founding family member has a percentage of share ownership in the company and/or serves on the board of commissioners or board of directors of the company. In contrast, this variable will equal 0 if the two conditions are not met (Anderson and Reeb, 2003a).

The information about the composition of the board of directors and board of commissioners can be obtained from the company's annual report. Next, the names of the board of directors and board of commissioners are explored through news related to the company and its founding family or direct statements in the company's profile or company's history. For example, PT Ace Hardware Indonesia Tbk (ACES) is a company whose majority shares are owned by the founder, PT Kawan Lama Sejahtera. Because the founder of PT Ace Hardware Indonesia Tbk is not an individual but a company, a search of the owner was carried out. The search proved that Wong Jin is the founder of PT Kawan Lama Sejahtera. Furthermore, Wong Jin's sons and daughter (Kuncoro Wibowo, Ijek Widyakrisnadi, Tarisa Widyakrisnadi, and Prabowo Widyakrisnadi) serve as the top management of the company. Thus, PT Ace Hardware Indonesia Tbk. is categorized as a family firm.

In some cases, there is a transfer of ownership control from the founding family to other family members who have majority shares, and these family members hold positions on the board of commissioners or board of directors. Such a company is still classified as a family firm in this study. In other cases, a company is owned by a foreign company and, due to limited information on the ownership of foreign companies, all foreign-owned companies are categorized as nonfamily firms.

The family generation variable consists of dummy variables that are separated into two other dummy variables. The first is DFOUNDER, which equals 1 if the family firm has a founding generation that serves on the board of commissioners and/or board of directors and 0 if these conditions are not met. The second is DDESCENDANT, which equals 1 if the family company has a descendant that serves on the board of commissioners and/or board of directors and 0 if these conditions are not met (Isakov \& Weisskopf, 2015).

The classification of whether a company is led by the founding generation or the next generation is based on individuals who serve as top management of the company, that is, the board of directors. If no founders or founding family members serve on the board of directors, the classification of the company is based on the board of commissioners. This is because the board of directors is considered more active in the daily operations of the company than the board of commissioners (Susanti \& Nidar, 2016). For example, PT Dharma Samudera Fishing Ind. Tbk (DSFI) is a family firm founded by Irwan Sutjiamidjaja. As the founder, he also served as president commissioner of the company. However, Herman and Hendra Sutjiamidjaja, as the sons of the founder, are on the board of directors. Therefore, PT Dharma Samudera Fishing Ind. Tbk. is considered a family firm led by descendants.

This study also included several control variables that can affect the influence of independent variables on the dependent variable. The cash ratio, which shows the amount of cash owned by the company, is expected to have a positive and negative consecutive effect on the level of dividends and leverage in connection with efforts to reduce agency costs. This ratio is calculated by comparing the amount of cash with the total assets of the company (Farinha, 2003). Growth opportunities as measured by calculating the average annual sales growth over the past three years are expected to have a negative and positive influence on dividends and leverage concerning corporate funding sources.

The level of corporate profitability is measured based on the return on assets (Lean et al., 2015; Pérez-González, 2006). With regard to corporate funding sources, profitability is expected to have a positive influence on dividends and leverage. In addition, the size of the company in the natural logarithm of the total assets of the company at the end of the reporting 
period (Setia-Atmaja, 2010) is expected to have positive and negative effects on dividends and leverage, in line with the easier access to capital markets. Mulyani et al. (2016) also include industrial sector control variables describing the differences in the level of dividend distribution and funding sources owned by each industrial sector with diverse characteristics. Likewise, the year of the research illustrates the differences in economic conditions and phenomena that occur annually. This study includes the year as a control variable, especially from 2012 through 2016.

\section{Model Specification}

This study uses multiple linear regression with the random effect research model. In accordance with Setia-Atmaja (2017), because there are dummy variables with properties that tend to remain unchanged over time, the analysis can only be captured by the random effect model. For example, companies that are classified as family companies tend to remain so classified for several periods of time, which is also consistent with the view that family companies maintain control of their ownership in the company. Variables with time-invariant properties cannot be identified by the least squares dummy variable (LSDV) model as expressed by Gujarati and Porter (2009). The random effect model is used to regress the four models of this research, as follows:

$$
\begin{aligned}
& \text { PAYOUT }_{\text {it }}=\alpha+\beta_{1} \text { DFAM }_{\text {it }}+\beta_{2} \mathrm{CASH}_{\text {it }}+\beta_{3} \text { GROWTH }_{\text {it }}+\beta_{4} P R O F I T_{i t}+\beta_{5} \text { SIZE }_{\text {it }} \\
& +\beta_{6-13} S E C T O R_{i t}+\beta_{14-18} Y E A R_{i t}+\varepsilon_{\text {it }} \\
& L E V_{i t}=\alpha+\beta_{1} D F A M_{i t}+\beta_{2} C_{A S H}+\beta_{3} G_{\text {ROWTH }}+\beta_{4} P R O F I T_{i t}+\beta_{5} \text { SIZE }_{i t} \\
& +\beta_{6-13} S_{E C T O R}+\beta_{14-18} Y E A R_{i t}+\varepsilon_{i t} \\
& \text { PAYOUT }_{i t}=\alpha+\beta_{1} \text { DFOUNDER }_{i t}+\beta_{2} \text { DDESCENDANT }_{i t}+\beta_{3} \text { CASH }_{\text {it }}+\beta_{4} G R O W T H_{i t} \\
& +\beta_{5} P R O F I T_{i t}+\beta_{6} S_{I Z E_{i t}}+\beta_{7-14} S E C T O R_{i t}+\beta_{15-19} Y E A R_{i t}+\varepsilon_{i t} \\
& L E V_{i t}=\alpha+\beta_{1} D_{F O U N D E R_{i t}}+\beta_{2} \text { DDESCENDANT it }+\beta_{3} \text { CASH }_{i t}+\beta_{4} G R O W T H_{i t} \\
& +\beta_{5} P R O F I T_{i t}+\beta_{6} S_{I Z E_{i t}}+\beta_{7-14} S E C T O R_{i t}+\beta_{15-19} Y E A R_{i t}+\varepsilon_{i t}
\end{aligned}
$$

\section{Results and Discussion}

\section{Descriptive Statistics and Univariate Analysis}

As shown in Table 4a, all firms in this sample have a leverage level of $57.91 \%$, while $80 \%$ of the sample are family firms that on average have 59.26\% leverage. Non-family firms have a lower leverage level than family firms (52.27\%), but this is not statistically different. Family firms in this sample have a significantly lower cash level, profitability, and size than non-family firms. Table 4a also shows that third-party-controlled family firms have the highest level of leverage, followed by descendant-led and founder-led family firms. Among other types of family firms, descendant-controlled family firms have the highest cash level, profitability, and size but the lowest growth opportunity.

Table 4a shows that all firms with eligibility to distribute dividends in Indonesia have on average a dividend payout ratio of $23.95 \%$. Family firms, which are $79.45 \%$ of the sample, on average distribute $22.08 \%$ of their net income as dividends, while non-family firms have a significantly higher dividend payout ratio of $31.18 \%$. Similar to the other set of samples, family firms have a significantly lower cash level, profitability, and size than non-family firms. Table 4a also shows that descendant-controlled family firms have the highest dividend payout ratios among the other types of family firms, followed by founder-controlled family firms, while professional-led family firms have the lowest dividend payout ratio. Consistent with the previous set of samples, descendant-controlled family firms have the highest cash level, profitability, and size, but the lowest growth opportunity. 
Table 4a. Descriptive Statistics of All Nonfinancial Firms in Indonesia 2012-2016

\begin{tabular}{|c|c|c|c|c|c|c|c|c|}
\hline \multirow[b]{2}{*}{ Variables } & \multicolumn{4}{|c|}{$\begin{array}{l}\text { All firms in Indonesia } \\
\qquad(\mathrm{N}=2,021)\end{array}$} & \multirow[t]{2}{*}{$\begin{array}{c}\begin{array}{c}\text { Family } \\
\text { firms }\end{array} \\
(\mathrm{N}=1,629)\end{array}$} & \multirow{2}{*}{$\begin{array}{l}\begin{array}{l}\text { Non-family } \\
\text { firms } \\
(\mathrm{N}=392)\end{array} \\
\text { Mean }\end{array}$} & \multirow[b]{2}{*}{ Diff. } & \multirow[b]{2}{*}{$p$-Value } \\
\hline & Mean & Std. Dev. & Min. & Max. & & & & \\
\hline LEV & 0.5791 & 0.8215 & 0.0002 & 16.8344 & 0.5926 & 0.5227 & -0.0699 & 0.1303 \\
\hline DFAM & 0.8060 & 0.3955 & 0 & 1 & - & - & - & - \\
\hline CASH & 0.0953 & 0.1089 & 0.0001 & 0.8007 & 0.0873 & 0.1287 & 0.0414 & $0.0000 * * *$ \\
\hline GROWTH & 0.4062 & 5.6761 & -1.7904 & 238.229 & 0.4392 & 0.2687 & 0.1705 & 0.5934 \\
\hline PROFIT & 0.0158 & 0.3614 & -10.9653 & 2.1921 & 0.0065 & 0.0545 & 0.0479 & $0.0184 * *$ \\
\hline \multirow[t]{3}{*}{ SIZE } & 14.6192 & 1.7466 & 8.5252 & 21.4879 & 14.5444 & 14.9301 & 0.3857 & $0.0001 * * *$ \\
\hline & \multicolumn{4}{|c|}{$\begin{array}{l}\text { Family firms in Indonesia } \\
\qquad(\mathrm{N}=1,629)\end{array}$} & $\begin{array}{l}\text { Founder- } \\
\text { controlled } \\
(\mathrm{N}=547)\end{array}$ & $\begin{array}{c}\text { Descendant } \\
\text {-controlled } \\
(\mathrm{N}=667)\end{array}$ & $\begin{array}{l}\text { Third-party- } \\
\text { controlled } \\
(\mathrm{N}=415)\end{array}$ & \\
\hline & Mean & Std. Dev. & Min. & Max. & Mean & Mean & Mean & $p$-Value \\
\hline LEV & 0.5926 & 0.8803 & 0.0002 & 16.8344 & 0.5090 & 0.5415 & 0.7849 & $0.0010 * * *$ \\
\hline DFOUNDER & 0.3358 & 0.4724 & 0 & 1 & - & - & - & - \\
\hline DDESCENDANT & 0.4095 & 0.4919 & 0 & 1 & - & - & - & - \\
\hline $\mathrm{CASH}$ & 0.0873 & 0.0983 & 0.0001 & 0.7297 & 0.0719 & 0.1093 & 0.0723 & $0.0000 * * *$ \\
\hline GROWTH & 0.4392 & 6.2869 & -1.7904 & 238.229 & 0.4794 & 0.1925 & 0.7829 & 0.1144 \\
\hline PROFIT & 0.0065 & 0.397 & -10.9653 & 2.1921 & 0.0160 & 0.0347 & -0.0512 & $0.0121 * *$ \\
\hline SIZE & 14.5444 & 1.7186 & 8.5252 & 21.4879 & 14.2269 & 14.8826 & 14.4193 & $0.0000 * * *$ \\
\hline
\end{tabular}

Table 4b. Descriptive Statistics of Firms with Eligibility to Distribute Dividends in Indonesia during 2012-2016

\begin{tabular}{|c|c|c|c|c|c|c|c|c|}
\hline \multirow[b]{2}{*}{ Variables } & \multicolumn{4}{|c|}{$\begin{array}{c}\text { All firms with eligibility } \\
\text { to distribute dividends in Indonesia } \\
(\mathrm{N}=1,484)\end{array}$} & \multirow{2}{*}{$\begin{array}{c}\begin{array}{c}\text { Family } \\
\text { firms } \\
(\mathrm{N}=1,179)\end{array} \\
\text { Mean }\end{array}$} & \multirow{2}{*}{$\begin{array}{l}\begin{array}{l}\text { Non-family } \\
\text { firms } \\
(\mathrm{N}=305)\end{array} \\
\text { Mean }\end{array}$} & \multirow[b]{2}{*}{ Diff. } & \multirow[b]{2}{*}{$p$-Value } \\
\hline & Mean & Std. Dev. & Min. & Max. & & & & \\
\hline PAYOUT & 0.2395 & 0.5064 & -1.8188 & 11.2787 & 0.2208 & 0.3118 & 0.0909 & $0.0052 * * *$ \\
\hline DFAM & 0.7945 & 0.4042 & 0 & 1 & - & - & - & . \\
\hline CASH & 0.1114 & 0.1152 & 0.0003 & 0.8007 & 0.1026 & 0.1457 & 0.0431 & $0.0000^{* * *}$ \\
\hline GROWTH & 0.4457 & 6.528 & -1.7904 & 238.229 & 0.4923 & 0.2657 & -0.2267 & 0.5890 \\
\hline PROFIT & 0.057 & 0.0965 & -1.7289 & 0.5974 & 0.0504 & 0.0825 & 0.0322 & $0.0000 * * *$ \\
\hline \multirow[t]{2}{*}{ SIZE } & 14.8453 & 1.5876 & 8.5252 & 21.4467 & 14.7584 & 15.1813 & 0.4229 & $0.0000 * *$ \\
\hline & \multicolumn{4}{|c|}{$\begin{array}{l}\text { Family firms with eligibility to distribute } \\
\text { dividends in Indonesia } \\
(\mathrm{N}=1,179)\end{array}$} & $\begin{array}{l}\text { Founder- } \\
\text { controlled } \\
(\mathrm{N}=398)\end{array}$ & $\begin{array}{l}\text { Descendant } \\
\text {-controlled } \\
(\mathrm{N}=525) \\
\end{array}$ & $\begin{array}{l}\text { Third-party- } \\
\text {-controlled } \\
(\mathrm{N}=256)\end{array}$ & \\
\hline Variables & Mean & Std. Dev. & Min. & Max. & Mean & Mean & Mean & $p$-Value \\
\hline PAYOUT & 0.2208 & 0.5407 & -1.8188 & 11.2787 & 0.2023 & 0.2606 & 0.1681 & $0.0001 * * *$ \\
\hline DFOUNDER & 0.3376 & 0.4731 & 0 & 1 & - & - & - & 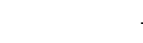 \\
\hline DDESCENDANT & 0.4453 & 0.4972 & 0 & 1 & - & - & - & 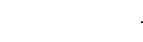 \\
\hline $\mathrm{CASH}$ & 0.1026 & 0.1044 & 0.0003 & 0.7297 & 0.0807 & 0.1252 & 0.0904 & $0.0000 * * *$ \\
\hline GROWTH & 0.4923 & 7.2833 & -1.7904 & 238.229 & 0.4553 & 0.1860 & 1.1781 & 0.2418 \\
\hline PROFIT & 0.0504 & 0.0933 & -1.7289 & 0.5974 & 0.0438 & 0.0605 & 0.0489 & $0.0000 * * *$ \\
\hline SIZE & 14.7584 & 1.517 & 8.5252 & 21.4467 & 14.4545 & 15.0167 & 14.7012 & $0.0000 * * *$ \\
\hline
\end{tabular}

Notes: PAYOUT = dividend payout ratio; $\mathrm{LEV}=$ leverage; DFAM = family ownership dummy variable; $\mathrm{CASH}=$ cash ratio; GROWTH = growth opportunity; PROFIT = profitability; SIZE = firm size

\section{Regression Results}

Table 5 displays the results of the random effect regression model used to examine the effect of family ownership and family generation on dividend payouts and leverage. 
Table 5. Random Effect Regression Results

\begin{tabular}{|c|c|c|c|c|}
\hline & Hypothesis 1 & Hypothesis 2 & Hypothesis 3 & Hypothesis 4 \\
\hline Variable & PAYOUT & LEV & PAYOUT & LEV \\
\hline DFAM & $\begin{array}{c}-0.0924 * * * \\
(-3.22)\end{array}$ & $\begin{array}{c}0.0743 * * \\
(2.42)\end{array}$ & 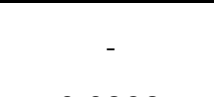 & 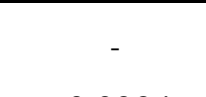 \\
\hline DFOUNDER & 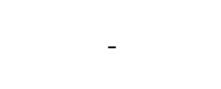 & 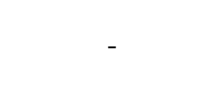 & $\begin{array}{c}0.0393 \\
(1.31)\end{array}$ & $\begin{array}{c}-0.0294 \\
(-1.21)\end{array}$ \\
\hline DDESCENDANT & - & - & $\begin{array}{c}0.0674 * * \\
(2.33)\end{array}$ & $\begin{array}{c}-0.0348 \\
(-1.43)\end{array}$ \\
\hline Constant & $\begin{array}{c}0.2846 * * * \\
(11.13)\end{array}$ & $\begin{array}{c}0.4529 * * * \\
(15.92)\end{array}$ & $\begin{array}{c}0.1493 * * * \\
\quad(6.26)\end{array}$ & $\begin{array}{c}0.5464 * * * \\
\quad(24.17)\end{array}$ \\
\hline Number of groups & 1,484 & 2,021 & 1,179 & 1,629 \\
\hline Number of observations & 366 & 443 & 291 & 356 \\
\hline \multirow[t]{2}{*}{ Overall $\mathrm{R}^{2}$} & 0.0217 & 0.0017 & 0.0154 & 0.0086 \\
\hline & Hypothesis 1 & Hypothesis 2 & Hypothesis 3 & Hypothesis 4 \\
\hline Variable & PAYOUT & LEV & PAYOUT & LEV \\
\hline DFAM & $\begin{array}{c}-0.5154 * * \\
(-2.09)\end{array}$ & $\begin{array}{c}0.0628^{* *} \\
(2.26)\end{array}$ & 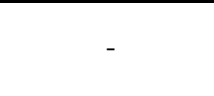 & 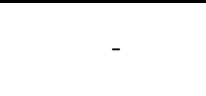 \\
\hline DFOUNDER & 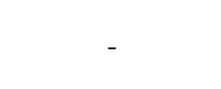 & 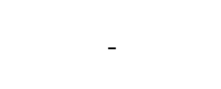 & $\begin{array}{c}0.0441 \\
(1.60)\end{array}$ & $\begin{array}{c}-0.0243 \\
(-1.08)\end{array}$ \\
\hline DDESCENDANT & - & - & $\begin{array}{c}0.0538 * * \\
(2.02)\end{array}$ & $\begin{array}{c}-0.0133 \\
(-0.59)\end{array}$ \\
\hline $\mathrm{CASH}$ & $\begin{array}{c}0.2068 * * * \\
\quad(2.90)\end{array}$ & $\begin{array}{c}-0.2143 * * * \\
(-4.71)\end{array}$ & $\begin{array}{c}0.2332 * * * \\
\quad(2.65)\end{array}$ & $\begin{array}{c}-0.1804 * * * \\
(-3.12)\end{array}$ \\
\hline GROWTH & $\begin{array}{c}-0.0912 * * * \\
(-3.57)\end{array}$ & $\begin{array}{c}0.0579 * * * \\
(5.71)\end{array}$ & $\begin{array}{c}-0.0600 * * \\
(-2.11)\end{array}$ & $\begin{array}{c}0.0499 * * * \\
\quad(4.30)\end{array}$ \\
\hline PROFIT & $\begin{array}{c}0.8923 * * * \\
\quad(8.26)\end{array}$ & $\begin{array}{c}-0.7232 * * * \\
(-17.22)\end{array}$ & $\begin{array}{c}0.7001 * * * \\
\quad(5.38)\end{array}$ & $\begin{array}{c}-0.7640 * * * \\
(-14.49)\end{array}$ \\
\hline SIZE & $\begin{array}{c}0.0296 * * * \\
\quad(4.81)\end{array}$ & $\begin{array}{c}-0.0013 \\
(-0.24)\end{array}$ & $\begin{array}{l}0.0224 * * * \\
\quad(3.15)\end{array}$ & $\begin{array}{c}-0.0051 \\
(-0.80)\end{array}$ \\
\hline Constant & $\begin{array}{c}-0.2083 * * * \\
(-2.05)\end{array}$ & $\begin{array}{c}0.4724 * * * \\
\quad(4.46)\end{array}$ & $\begin{array}{c}-0.1179 * * * \\
(-1.59)\end{array}$ & $\begin{array}{c}0.6308 * * * \\
\quad(5.33)\end{array}$ \\
\hline Dummy variable SECTOR & Yes & Yes & Yes & Yes \\
\hline Dummy variable YEAR & Yes & Yes & Yes & Yes \\
\hline Number of groups & 1,484 & 2,021 & 1,179 & 1,629 \\
\hline Number of observations & 366 & 443 & 291 & 356 \\
\hline Overall $\mathrm{R}^{2}$ & 0.2000 & 0.1808 & 0.1311 & 0.2010 \\
\hline
\end{tabular}

Notes: PAYOUT = dividend payout ratio; LEV = leverage; DFAM = family ownership dummy variable; DFOUNDER $=$ founder-controlled dummy variable; DDESCENDANT $=$ descendant-controlled dummy variable; $\mathrm{CASH}=$ cash ratio; GROWTH $=$ growth opportunity; PROFIT $=$ profitability; SIZE $=$ firm size $* * *=$ significance level of $1 \%,{ }^{* *}=$ significance level of $5 \%,{ }^{*}=$ significance level of $10 \%$

Column 1 in Table 5 shows the effect of family ownership toward dividend payouts, revealing a significant negative relationship at the $5 \%$ level, consistent with the first hypothesis. The same results are also reported in previous research conducted in Indonesia (Mulyani et al., 2016; Setia-Atmaja, 2017). Lower dividend payouts in family firms are also in line with the entrenchment effect (Easterbrook, 1984; Shleifer \& Vishny, 1997). By paying lower dividends, the family, as the main controlling shareholder of the company, may increase the level of cash that can be expropriated. This activity is also supported by the tunneling concept (Johnson et al., 2000). Family as the main controlling shareholder may be able to expropriate by tunneling the company's assets or wealth at the expense of minority shareholders, thus reducing the dividends 
distributed to shareholders. Operating in Indonesia, as a country with low investor protection, also increases the possibility of expropriation (Faccio et al., 2001a).

Consistent with the second hypothesis, Table 5, column 2, shows a significant positive relationship at the 5\% level between family ownership and firms' leverage. Research by SetiaAtmaja (2010) on Australian firms and Mulyani et al. (2016) in Indonesia also confirm this relationship. The positive effect on firms' leverage shows that family firms have significantly higher debt (liabilities) than non-family firms, which is consistent with the alignment effect (Wang, 2006). The presence of family within the firm can result in more effective supervision and therefore reductions in agency cost. Moreover, leverage is used as a control mechanism (Jensen, 1986) since leverage can minimize the availability of cash through interest and loan principal payment. According to pecking order theory, leverage can also be used to prevent share dilution of ownership (Gómez-Mejía, Makri \& Larraza-Kintana, 2010).

Column 3 in Table 5, which shows the effect of family generation on dividend payout, reveals insignificant results for the dummy variable DFOUNDER, but is significant at the 5\% level for the dummy variable DDESCENDANT. Relating this result to the intergenerational comparison shown in Table $4 \mathrm{~b}$, one can see that descendant-led family firms pay more dividends than any other generation, which is in line with the family income needs concept (Isakov \& Weisskopf, 2015). As family firms are passed to the next generation, more family members depend on the income source from dividends distributed by the firm. Higher dividend payouts are used to increase the active role of later generation family members and to compensate family members who are not involved in an active management position.

The result of the first hypothesis indicates a lower level of dividend payments in family firms than in non-family firms. However, family firms run by the next generation have higher dividend payments than other family firms. Family firms that are still run by the founding family member or a third party are less generous in paying dividends because they use the cash flow within the company, without giving back to minority shareholders (Shleifer \& Vishny, 1997). This is done to keep the wealth within the company for personal gain (expropriation) or to invest the money for the good of the company so that it can be passed on to the next generation.

As shown in Table 5, column 4, neither of the dummy variables DFOUNDER or DDESCENDANT has a significant effect on leverage. This insignificant result between family generation and leverage is consistent with Anderson and Reeb (2003a); they report no significant difference in risk profiles between generations that lead Indonesian family firms.

Using only two dummy variables, DFOUNDER and DDESCENDANT, results in limitations in interpreting the findings comparing three types of family firm management. Therefore, to deepen the results of the regression test, a Welch F-test that is robust to unequal variance (Derrick, Toher \& White, 2016) is performed. Table 6 shows the distribution of leverage between generations and the Welch F-test results.

Table 6. Welch Test Result (Hypothesis 4)

\begin{tabular}{ccccc}
\hline Variable & $\begin{array}{c}\text { Founder } \\
\text { (547 observations) }\end{array}$ & $\begin{array}{c}\text { Descendant } \\
\text { (667 observations) }\end{array}$ & $\begin{array}{c}\text { Third Party } \\
\text { (415 observations) }\end{array}$ & Welch P-Value \\
\hline LEV & 0.5090 & 0.5415 & 0.7849 & $0.0010^{* * *}$ \\
\hline
\end{tabular}

Notes: LEV = leverage

$* * *=$ significance level of $1 \%, * *=$ significance level of $5 \%, *=$ significance level of $10 \%$

Founder-and descendant-controlled family firms have similar data distribution, with descendant-controlled family firms having slightly higher leverage. This result is consistent with Muñoz-Bullon, Sanchez-Bueno, and Suárez-González (2018), who find that descendants tend to use diversification strategy and therefore require external funding. However, the third-party or professional-controlled family firms have the highest mean leverage. 
Third-party-controlled family firms have more supervision and more views from experts in their fields compared to other types of family firms. This is confirmed by Barth et al. (2005), who find that family firms run by external parties are more productive than those run by family members due to differences in expertise. With independence and better productivity, third-partycontrolled family firms are more open to loan funding, along with having additional supervision from creditors and openness to investment and growth opportunities. Leverage is used as a control mechanism to mitigate agency problems through additional supervision from external parties or creditors. This differs from founder- or descendant-controlled family firms, which use leverage as a mechanism to retain the family ownership in the firm. Therefore, the third party uses its position to set better oversight policies, mainly through the use of higher leverage as discussed in the results of the second hypothesis, along with the low dividend rate as discussed in the results of the first and third hypotheses.

\section{Conclusion}

This study analyzes the influence of family ownership and family generation on the level of company dividend payments and leverage. This research was conducted on public companies in Indonesia that were listed on the Indonesia Stock Exchange for 2012 to 2016. Based on the results of panel data regression with the random effect model, family ownership has a significant negative effect on the level of cash dividend distribution and a significant positive effect on leverage. This result is consistent with Mulyani et al. (2016) that show family-controlled firms in Indonesia use leverage instead of dividends to alleviate agency problem. However, descendantcontrolled family firms have a significant positive effect on dividend payments, while professional-controlled family firms have the lowest level of dividend payout and the highest level of leverage compared to founder- and descendant-led family firms.

The research process in this study has certain limitations. For instance, the study does not identify the percentage share of ownership or voting rights owned by the family due to difficulties in identifying a private company's owner. In addition, this study only classifies family ownership through the ability to make decisions in the company via a management position or share ownership without looking at the percentage of ownership, significant influence, voting rights, or cash flow rights and without distinguishing whether the share ownership is direct or indirect.

Future researchers can more deeply analyze the motives of family companies in having lower dividend rates than non-family companies. Therefore, one can determine whether the low distribution is due to expropriation or the need to replant the free cash flow as a source of corporate funding. In addition, the number of family members on the board of directors or board of commissioners can also support the discussion of family income needs.

This research has several implications for various parties, especially for countries with weak investor protection. First, readers and the public can broaden their knowledge about the characteristics of family firms and family generations. For investors, the results of this study can provide additional information regarding the financial ratios of family firms and family generations that can be taken into consideration in making investments. For regulators, due to the possibility of expropriation through low dividend distribution to family firms, all companies may need to increase transparency and improve corporate governance practices, such as compensation and remuneration system reports and ownership structure reports. For creditors, this research can provide additional information related to the decision to lend funds and encouragement to improve functions as external parties that oversee the operations of family firms. Finally, family firms can consider increasing the proportion of independent parties in the top management ranks to reduce any expropriation tendencies. 


\section{References}

Anderson, R. C., \& Reeb, D. M. (2003a). Founding-family ownership and firm performance: Evidence from the S\&P 500. Journal of Finance, 58(3), 1301-1328.

Anderson, R. C., Mansi, S. A., \& Reeb, D. M. (2003). Founding family ownership and the agency cost of debt. Journal of Financial Economics, 68(2), 263-285. Retrieved from https://doi.org/10.1016/S0304- 405X(03)00067-9

Asian Development Bank. (2000). Corporate governance and finance in East Asia: A study of Indonesia, Republic of Korea, Malaysia, Philippines, and Thailand. Consolidated Report 1. Manila: Asian Development Bank.

Attig, N., Boubakri, N., El Ghoul, S., \& Guedhami, O. (2016). The global financial crisis, family control, and dividend policy. Financial Management, 45(2), 291-313.

Barth E., Gulbransen T., and Schønea P., (2005). FAmily ownership and productivity": the role of owner-management. Journal of Corporate Finance. Vol 11(1-2), 107-127.

Bobillo, A. M., Rodríguez-Sanz, J. A., \& Tejerina-Gaite, F. (2013). Shareholder activism and internationalization in the family firm. Journal of Business Economics and Management, 14(5), 867-885.

Chen, Z., Cheung, Y. L., Stouraitis, A., \& Wong, A. W. S. (2005). Ownership concentration, firm performance, and dividend policy in Hong Kong. Pacific-Basin Finance Journal, 13(4), 431-449. Retrieved from https://doi.org/10.1016/j.pacfin.2004.12.001

Claessens, S., Djankov, S., \& Lang, L. H. P. (2000). The separation of ownership and control in East Asian corporations. Journal of Financial Economics, Vol. 58(1-2), 81-112.

Derrick, B., Toher, D., \& White, P. (2016). Why Welch's test is type I error robust. Quantitative Methods in Psychology, 12(1).

Duygun, M., Guney, Y., \& Moin, A. (2018). Dividend policy of Indonesian listed firms: The role of families and the state. Economic Modelling, 75, 336-354.

Easterbrook, F. (1984). Two agency-cost explanations of dividends. American Economic Review, 74(4), 650-659.

Eisenhardt, K. M. (1989). Agency theory: An assessment and review. Academy of Management Review, 14(1), 57-74. Retrieved from https://doi.org/10.2307/258191

Faccio, M., Lang, L. H., \& Young, L. (2001a). Dividends and expropriation. American Economic Review, 91(1), 54-78.

Faccio, M., Lang, L. H., \& Young, L. (2001b). Debt and corporate governance. In Meetings of Association of Financial Economics in New Orleans.

Fahlenbrach, R. (2009). Founder-CEOs, investment decisions, and stock market performance. Journal of Financial and Quantitative Analysis, 44 (2), 439-466.

Farinha, J. (2003). Dividend policy, corporate governance and the managerial entrenchment hypothesis: An empirical analysis. Journal of Business Finance \& Accounting, 30(9-10), 1173-1209.

Gómez-Mejía, L. R., Haynes, K. T., Núñez-Nickel, M., Jacobson, K. J. L., \& Moyano-Fuentes, H. (2007). Socioemotional wealth and business risk in family-controlled firms: Evidence from Spanish olive oil mills. Administrative Science Quarterly, 52(1), 106-137.

Gómez-Mejía, L. R., Makri, M., \& Larraza-Kintana, M. (2010). Diversification decisions in family- 
controlled firms. Journal of Management Studies, 47, 223-252.

Gujarati, D. N., \& Porter, D. C. (2009). Basic econometrics (5th ed.). New York: McGrawHill.

Holderness, C. G., \& Sheehan, D. P. (1988). The role of majority shareholders in publicly held corporations: An exploratory analysis. Journal of Financial Economics, 20, 317-346.

Isakov, D., \& Weisskopf, J. P. (2015). Pay-out policies in founding family firms. Journal of Corporate Finance, 33, 330-344. Retrieved from https://doi.org/10.1016/j.jcorpfin.2015.01.003

Jensen, M. C. (1986). Agency costs of free cash flow, corporate finance, and takeovers. American Economic Review, 76(2), 323-329. Retrieved from http://www.jstor.org/stable/1818789

Jensen, M. C., \& Meckling, W. H. (1976). Theory of the firm: Managerial behavior, agency costs and ownership structure. Journal of Financial Economics, 3(4), 305-360.

Johnson, S., La Porta, R., Lopez-de-Silanes, F., \& Shleifer, A. (2000). Tunneling. American Economic Review, 90(2), 22-27. Retrieved from http://www.jstor.org/stable/117185

Keasey, K., Martinez, B. \& Pindado, J. (2015). Young family firms: Financing decisions and the willingness to dilute control. Journal of Corporate Finance, 34, 47-63.

La Porta, R., Lopez-de-Silanes, F., \& Shleifer, A. (1999). Corporate ownership around the world. Journal of Finance 54, 471-517.

La Porta, R., Lopez-de-Silanes, F., Shleifer, A., \& Vishny, R. (2000). Agency problems and dividend policies around the world. Journal of Finance, 55, 1-33.

Lean, H. H., Ting, I. W. K., \& Kweh, Q. L. (2015). Ownership concentration, family ownership and leverage: Evidence from Malaysia. Malaysian Journal of Economic Studies, 52, 117133.

Lo, H. C., Ting, I. W. K., Kweh, Q. L., \& Yang, M. J. (2016). Nonlinear association between ownership concentration and leverage: The role of family control. International Review of Financial Analysis, 46, 113-123.

Miller, D., Brenton-Miller, I., Lester, R.H., and CannellaJr A.A. (2007). Are family firms really superior performers? Journal of Corporate Finance. Vol 13(5), 829-858.

Moin, A., Guney, Y., \& El Kalak, I. (2019). The effects of ownership structure, sub-optimal cash holdings and investment inefficiency on dividend policy: Evidence from Indonesia. Review of Quantitative Finance and Accounting, 1-44.

Mulyani, E., Singh, H., \& Mishra, S. (2016). Dividends, leverage, and family ownership in the emerging Indonesian market. Journal of International Financial Markets, Institutions and Money, 43, 16-29. Retrieved from https://doi.org/10.1016/j.intfin.2016.03.004

Muñoz-Bullon, F., Sanchez-Bueno, M. J., \& Suárez-González, I. (2018). Diversification decisions among family firms: The role of family involvement and generational stage. $B R Q$ Business Research Quarterly, 21(1), 39-52. Retrieved from https://doi.org/10.1016/j.brq.2017.11.001

Myers, S. C., \& Majluf, N. S. (1984). Corporate financing and investment decisions when firms have information that investors do not have. Journal of Financial Economics, 13(2), 187221. Retrieved from https://doi.org/10.1016/0304-405X(84)90023-0

Pérez-González, F. (2006). Inherited control and firm performance. American Economic Review, 96(5), 1559-1588. 
PricewaterhouseCoopers (2014). Family Business Survey 2014: Country Report Indonesia. Retrieved December 13, 2017, from https://www.pwc.com/id/en/publications/assets/Family-Business-Survey- 2014-CountryReport-Indonesia.pdf

Rankin, M., Stanton, P., McGowan, S., Ferlauto, K., \& Tilling, M. (2012). Contemporary issues in accounting ( 1 st ed). USA: John Wiley Inc.

Sciascia, S., Mazzola, P., \& Kellermanns, F. W. (2014). Family management and profitability in private family-owned firms: Introducing generational stage and the socioemotional wealth perspective. Journal of Family Business Strategy, 5(2), 131-137. Retrieved from https://doi.org/10.1016/j.jfbs.2014.03.001

Setia-Atmaja, L. (2010). Dividend and debt policies of family controlled firms: The impact of board independence. International Journal of Managerial Finance, 6(2), 128-142. Retrieved from https://doi.org/10.1108/17439131011032059

Setia-Atmaja, L. (2017). The impact of family control on dividend policy: Evidence from Indonesia. International Research Journal of Business Studies, 9(3). 147-156.

Setia-Atmaja, L., Tanewski, G. A., \& Skully, M. (2007). How do family ownership and control affect board structure, dividends and debt? Australian evidence. Proceeding of the 16th European Financial Management Association Conference, Vienna, Austria.

Setianto, R. H., \& Sari, P. K. (2017). Perusahaan keluarga dan kebijakan dividen di Indonesia. Jurnal Siasat Bisnis, 21(2), 107-118.

Setiawan, D., Bandi, B., Kee Phua, L., \& Trinugroho, I. (2016). Ownership structure and dividend policy in Indonesia. Journal of Asia Business Studies, 10(3), 230-252. Retrieved from https://doi.org/10.1108/JABS-05-2015-0053

Shleifer, A., \& Vishny, R. W. (1986). Large Shareholders and Corporate Control. Journal of Political Economy, 94(3, Part 1), 461-488.

Shleifer, A., \& Vishny, R. W. (1997). A survey of corporate governance. Journal of Finance, 52 (2), 737-783. Retrieved from https://doi.org/10.1108/03074351111175100

Susanti L. and Nidar S. R., (2016). Corporate Board and Firm Value: Perspective Two-Tier Board System in Indonesia. International Journal of Scientific \& Technology Research. Vol. 5 (5), 300-305.

Vieira, E. S. (2011). Investor sentiment and the market reaction to dividend news: European evidence. Managerial Finance, 37(12), 1213-1245.

Villalonga, B., \& Amit, R. (2006). How do family ownership, control and management affect firm value? Journal of Financial Economics, 80(2), 385-417. Retrieved from https://doi.org/10.1016/j.jfineco.2004.12.005

Wang, D. (2006). Founding family ownership and earnings quality. Journal of Accounting Research, 44(3), 619-656.

Wei, Z., Wu, S., Li, C., \& Chen, W. (2011). Family control, institutional environment and cash dividend policy: Evidence from China. China Journal of Accounting Research, 4(1-2), 29-46. Retrieved from https://doi.org/10.1016/j.cjar.2011.04.001 